Orijinal araştırma (Original article)

\title{
Effects of entomopathogenic nematodes, Heterorhabditis bacteriophora (Poinar) and Steinernema carpocapsae (Weiser), in biological control of Agrotis segetum (Denis \& Schiffermüller) (Lepidoptera: Noctuidae)
}

\author{
Agrotis segetum (Denis \& Schiffermüller) (Lepidoptera: Noctuidae)' un biyolojik \\ mücadelesinde entomopatojen nematodlar, Heterorhabditis bacteriophora (Poinar) ve \\ Steinernema carpocapsae (Weiser)' In etkinlikleri
}

Maria GOUDARZI ${ }^{1} \quad$ Mohammad Reza MOOSAVI $^{1^{*}} \quad$ Rahil ASADI $^{2}$

\section{Summary}

Agrotis segetum (Denis \& Schiffermüller) (Lepidoptera: Noctuidae) is one of the most serious pests in Iran that attacks nearly all vegetables. Using synthetic insecticides is the main controlling method of this pest. Human and environmental health hazards on insecticides usage encourage scientists to search for alternative safer methods. This research is devised to evaluate the potential of two indigenous entomopathogenic nematodes against this pest. Ability of different concentrations of infective juveniles to infect penultimate and last instars larvae, pre-pupa and pupa was assessed under laboratory condition after 12, 24 and $48 \mathrm{~h}$. Susceptibility of larval stages, pre-pupa and pupa to different concentrations of both entomopathogenic nematodes was evaluated in a pot experiment. Final instar larvae was the most susceptible stage in both laboratory and greenhouse condition. Pre-pupa was more vulnerable to entomopathogenic nematodes as compared with pupa. The mortality increased with increasing in the time of exposure. After 12 hours, the $\mathrm{LD}_{50}$ of Heterorhabditis bacteriophora (Poinar) and Steinernema carpocapsae (weiser) on final instar larvae were 34 and 56 infective juveniles per $10 \mathrm{~cm}$ Petri dish respectively. About 98 and $90 \%$ of final instar larvae were parasitized five days after exposing to $H$. bacteriophora and $S$. carpocapsae in the greenhouse. According to the results, these two indigenous entomopathogenic nematodes have good potentials in managing $A$. segetum.

Keywords: Biocontrol, common cutworm, lethal dose, pest management, turnip moth

\section{Özet}

Agrotis segetum (Denis \& Schiffermüller) (Lepidoptera: Noctuidae), İran'da hemen hemen tüm sebze bitkilerine saldıran en önemli zararlılardan birisidir. Zararlının mücadelesinde sentetik kimyasallar kullanılmaktadır. İnsektisit kullanımının çevreye insan hayatına vermiş olduğu olumsuz etkileri ortadan kaldırmak için bilim insanları zararlılar ile mücadele için alternatif ve daha güvenli metotlar araştırmaktadırlar. Bu çalışma bu zararlıya karşı iki entomopatojen nematod türünün potansiyelini belirlemek için planlanmıştır. Farklı konsantrasyondaki nematod juvenillerinin zararıının sondan bir önceki, son, pre-pupa ve pupa dönemleri üzerindeki etkisi laboratuvar koşullarında uygulamadan 12, 24 ve 48 saat sonra değerlendirilmiştir. Larva dönemlerinin, pre-pupa ve pupa dönemlerinin her iki nematodun farklı konsantrasyonlarına uygunluğu saksı denemeleri ile belirlenmiştir. Zararlının son larva dönemi hem laboratuvar hem de sera koşullarında nematodlar için en uygun dönem olarak belirlenmiştir. Pupa dönemi ile karşılaştırıldığında pre-pupa dönemi nematodlara karşı daha hassas bulunmuştur. Ölüm oranı zararlının nematodla muamele süresi arttıkça artmıştır. Uygulamadan 12 saat sonra Heterorhabditis bacteriophora (Poinar) ve Steinernema carpocapsae (Weiser)' nın son larva dönemine karşı $10 \mathrm{~cm}$ çapındaki Petri kabında LD50 değeri sırasıyla 34 ve 56 juvenil bulunmuştur. Serada $H$. bacteriophora ve $S$. carpocapsae uygulamalarından beş gün sonra son larva dönemlerinin yaklaşık \% 98 ve 90'nın nematodlar tarafından parazitlendiği tespit edilmiştir. Araştırma sonuçlarına göre her iki entomopatojen nematod türünün $A$. segetum mücadelesinde önemli bir potansiyele sahip olduğu belirlenmiştir.

Anahtar sözcükler: Biyolojik mücadele, bozkurt, letal doz, zararlılarla mücadele, şalgam güvesi

\footnotetext{
${ }^{1}$ Department of Plant Pathology, Marvdasht Branch, Islamic Azad University, Marvdasht, Iran

2 Department of Entomology, Marvdasht Branch, Islamic Azad University, Marvdasht, Iran.

* Sorumlu yazar (Corresponding author) email: rmmoosavi@yahoo.com

Alınış (Received): 29.04.2015 Kabul ediliş (Accepted): 11.06.2015

Çevrimiçi Yayın Tarihi (Published Online): 30.08.2015
} 
Effects of entomopathogenic nematodes, Heterorhabditis bacteriophora (Poinar) and Steinernema carpocapsae (Weiser), in biological control of Agrotis segetum (Denis \& Schiffermüller) (Lepidoptera: Noctuidae)

\section{Introduction}

Larvae of Agrotis segetum (Denis \& Schiffermüller) (Lepidoptera: Noctuidae) have a widespread host range and can attack the roots and lower stems of their host plants. Their presence is often revealed only when the plants are already damaged severely (Bourner et al., 1992; Bowden et al., 1983). This moth is considered as one of the most serious pests on vegetables and cereals throughout Asia, Europe and parts of Africa that could impose a considerable economic loss (Jakubowska et al., 2005). Management of this pest is difficult due to their soil-dwelling habit. The current control method is mainly based on different kinds of insecticides that have met varying success (Sevim et al., 2010). Hazards on environment and human health have encouraged researchers to find some alternative safe measures for chemicals (Moosavi \& Zare, 2012).

Biological control by entomopathogenic nematodes (EPNs) has attracted much attention in the last few decades (Hunt, 2007). Among all EPNs, members of the families Steinernematidae and Heterorhabditidae are considered effective (Hominick, 2002; Adams et al., 2006) with a great potential for biological control, especially against soil-inhabiting insects (Ehler, 1990; Koppenhöfer, 2000; Sharma et al., 2011). Rapid death of the host insects, searching ability of hosts, easy to use, long-term effect, surviving ability in environment, being safer to non-target organisms and compatibility with many chemical insecticides are some of EPNs' favorable features that make them suitable as biocontrol agents (Koppenhöfer \& Kaya, 2002; Vashisth et al., 2013). There is significant variation among different species/isolates of EPNs in their host range, environmental requirement for survival and pathogenicity (Bedding, 1990; Lacey \& Georgis, 2012). Indigenous isolates of EPNs may have greater potential in biocontrol as a result of their compatibility to native habitats (Griffin et al., 2005); therefore, it is rational to evaluate the ability of locally adapted species or isolates in controlling significant pests of that region (Moosavi \& Zare, 2015).

Lepidopterans are considered as a susceptible host for Steinernematids and Heterorhabditids (Vashisth et al., 2013). Additionally, existence of the common cutworm's larval stages below ground, make them an appropriate target for biocontrol by EPNs (Georgis et al., 2006). Thus the present study was designed to evaluate the effect of two Iranian species of EPNs (Damani Zamani et al., 2015) on biological control of the common cutworm, Agrotis segetum, in laboratory and greenhouse.

\section{Materials and Methods}

\section{Preparation of entomopathogenic nematodes inoculum}

Two indigenous nematode species maintained alive in the Marvdasht branch, Islamic Azad University EPN Collection were used in this research. Enough population of nematodes were reared on Galleria mellonella L. (Lepidoptera: Pyralidae) larvae. The greater wax moth larvae was collected from infected hives and reared on an artificial medium (Metwally et al., 2012).

Petri dishes $(100 \times 15 \mathrm{~mm})$ were lined with two pieces of filter papers and were moistened with 2 or $3 \mathrm{ml}$ of water containing 200-300 infective juveniles (IJs) of Steinernema carpocapsae (Sc) or Heterorhabditis bacteriophora $(\mathrm{Hb})$. Ten late instar larvae of the greater wax moth were exposed to IJs of nematodes by putting on filter papers (Nguyen, 2007). The IJs migrated away from the host cadaver upon emergence and were harvested on the White trap (White, 1927; Ehlers \& Shapiro-llan, 2005). IJs were stored at $12^{\circ} \mathrm{C}$ (Stock \& Goodrich-Blair, 2012) for one week and were permitted to acclimatize at room temperature for $1 \mathrm{~h}$ before using as inoculum. The viability of IJs in nematode suspension was assessed by observation of movement under a stereomicroscope.

\section{Collecting and rearing of Agrotis segetum}

The common cutworm larvae were collected from different tomato fields near Marvdasht, south west of Iran. In order to prepare enough larvae for the experiment, sufficient population of Agrotis segetum was established in growth chamber at a temperature of $23^{\circ} \mathrm{C}$, relative humidity $60 \%$ and a photoperiod of 17:7 (L:D) (Rosen, 2002). Different healthy larval stages and pupae were selected to be used in pathogenicity test. 


\section{Pathogenicity test}

\section{Laboratory experiment}

The virulence of two indigenous nematode species against pre-pupa, pupa and two last larval stages $\left(4^{\text {th }}\right.$ and $5^{\text {th }}$ instar larvae) of common cutworm was evaluated in a laboratory experiment. Ten larvae in fourth or fifth instar stage were put on two moist filter papers in a $100 \times 15 \mathrm{~mm}$ Petri dish inoculated with $1 \mathrm{ml}$ of water containing different concentrations of IJs. The experiment was established in a completely randomized design with a factorial treatment arrangement consisting of two nematode species ( $\mathrm{Hb}$ and Sc) and 4 application rates (25, 50,75, and $100 \mathrm{IJs} / \mathrm{dish})$. The number of dead larvae was recorded at 3 different exposure times (24, 48 and 72 hour). Control plates were treated with distilled water only. Five replicates were considered for each treatment and Petri dishes were kept at $27 \pm 1{ }^{\circ} \mathrm{C}$. Dead larvae were recognized according to change in their body color. Cadavers were transferred to White trap to confirm nematode infection.

The susceptibility of pre-pupal and pupal stages of the common cutworm was also assessed in soil. Ten insect's pre-pupa or pupa was placed at the bottom of a dish with $3 \mathrm{~cm}$ depth and the dish was filled with $23 \mathrm{~g}$ of moistened sterile sandy loam soil (sand $67.3 \%$, clay $12.1 \%$, silt $20.6 \%$, organic matter $3.5 \%$ and $\mathrm{pH} 7.5)$. The experiment was conducted at $27 \pm 1{ }^{\circ} \mathrm{C}$ in a factorial arrangement consisting of two nematode species ( $\mathrm{Hb}$ and Sc) and 3 application rates $\left(50,100\right.$ and $200 \mathrm{IJs} / \mathrm{cm}^{2}$ of soil) with five replicates. IJs of two nematode species were applied on the soil surface. The amount of water in nematode suspension was adjusted that the final soil moisture level reached to $10 \%(\mathrm{w} / \mathrm{w})$. Control plates were treated with distilled water only. Mortality of the pre-pupae and pupae was recorded 48 and $72 \mathrm{~h}$ after inoculation by transferring on individual White trap to verify the mortality was due to nematode infection.

\section{Greenhouse experiment}

$500 \mathrm{~g}$ plastic pots $(15 \mathrm{~cm}$ diameter, $15 \mathrm{~cm}$ depth) were filled with sterile sandy loam soil (sand $67.3 \%$, clay $12.1 \%$, silt $20.6 \%$, organic matter $3.5 \%$ with $\mathrm{pH} 7.5$ ) and two disinfected tomato seeds (cv. Early Urbana) were sown in each pot. After two weeks, one seedling was selected and the other was eliminated. Each nematode species was evenly applied on to the soil surface of each pot at the rate of 8 , 10 and $20 \mathrm{IJs} / \mathrm{g}$ soil (respectively equal to $25.5,28.3$ and $56.6 \mathrm{IJs} \mathrm{cm}^{-2}$ soil). After $48 \mathrm{~h}$, the pots were separately inoculated with ten larvae $\left(2^{\text {nd }}\right.$ to $5^{\text {th }}$ larval stages), pre-pupae and 3-days-old pupae of the common cutworm. Different developmental stages of insect were put at depth of $2 \mathrm{~cm}$ and were covered with soil. After five days, the number of dead insects was counted. Cadavers were transferred to White trap to confirm nematode infection. The experiment was carried out in a completely randomized design with five replicates.

\section{Statistical analysis}

The mortality percentage of each treatment was corrected according to the control treatment values by Abbott's formula (Abbott, 1925). Statistical analyses were carried out by SAS software (version 9.1.3; SAS Institute, Cary, NC) (1990). Mean values were separated using Duncan's Multiple Range Test $(P<0.05)$. Polynomial regression was performed on larval mortality data in the laboratory experiment to determine the lethal dosage which kills $50 \%\left(L_{50}\right)$ and $90 \%\left(L_{90}\right)$ of insect's population for each nematode species (Sigmaplot 11, Systat Software Inc., San Jose, CA). The effect of same concentrations of $H$. bacteriophora and $S$. carpocapsae on mortality of each developmental stage of $A$. segetum in greenhouse was compared by the Independent-Samples T Test. 
Effects of entomopathogenic nematodes, Heterorhabditis bacteriophora (Poinar) and Steinernema carpocapsae (Weiser), in biological control of Agrotis segetum (Denis \& Schiffermüller) (Lepidoptera: Noctuidae)

\section{Results}

\section{Laboratory experiment}

The mortality of insect's larvae was significantly influenced by nematode species ( $N$ ), nematode concentration $(\mathrm{C})$, and their interaction $(\mathrm{N} \times \mathrm{C})$ (Table1). At all exposure times, $H$. bacteriophora caused a significantly greater mortality in $4^{\text {th }}$ and $5^{\text {th }}$ larval stages of $A$. segetum than $S$. carpocapsae did. Similarly, the highest larval mortality was achieved when EPNs were applied at a dose of $100 \mathrm{IJs} / \mathrm{dish}$.

Table 1. Analysis of variance for mortality of $4^{\text {th }}$ and $5^{\text {th }}$ instar larvae of the common cutworm (Agrotis segetum) on filter paper when they exposed to four different concentrations (25, 50, 100 and 200 IJs / Petri dish) of Heterorhabditis bacteriophora and Steinernema carpocapsae in a factorial design

\begin{tabular}{|c|c|c|c|c|c|c|}
\hline \multirow{3}{*}{ Source ${ }^{a}$} & \multicolumn{6}{|c|}{ Mean squares } \\
\hline & \multicolumn{3}{|c|}{ L4 mortality percent $^{\text {b }}$} & \multicolumn{3}{|c|}{ L5 mortality percent ${ }^{b}$} \\
\hline & $12 \mathrm{~h}$ & $24 \mathrm{~h}$ & $48 \mathrm{~h}$ & $12 \mathrm{~h}$ & $24 \mathrm{~h}$ & $48 \mathrm{~h}$ \\
\hline $\mathrm{N}$ & $390.6^{* *}$ & $1322.5^{* *}$ & $1232.5^{* *}$ & $1050.6^{* *}$ & $1500.6^{* *}$ & $1322.5^{* *}$ \\
\hline $\mathrm{C}$ & $3377.3^{* *}$ & $3407.5^{* *}$ & $4026.7^{* *}$ & $3029^{* *}$ & $3914^{* *}$ & $4689.2^{* *}$ \\
\hline $\mathrm{N} \times \mathrm{C}$ & $167.3^{* *}$ & $174.2^{* *}$ & $142.5^{* *}$ & $139^{* *}$ & $174^{* *}$ & $149.2^{* *}$ \\
\hline Error & 31.87 & 24.37 & 22.2 & 35.3 & 20.6 & 20 \\
\hline C.V. (\%) & 18.3 & 32.7 & 24.5 & 15.2 & 27.4 & 29.2 \\
\hline
\end{tabular}

: significant at $1 \%$ probability levels

${ }^{a} \mathrm{~N}=$ nematode species, $\mathrm{C}=$ nematode concentration

${ }^{\mathrm{b}}$ The corrected mortality percents were considered for analysis.

The mortality percent of $4^{\text {th }}$ and $5^{\text {th }}$ instar larvae was increased with increase in exposure time. When $L_{4}$ and $L_{5}$ were exposed to EPNs for similar time span, $L_{5}$ was more vulnerable than $L_{4}$ was. After $48 \mathrm{~h}, H$. bacteriophora and S. carpocapsae caused $98 \%$ and $87 \%$ mortality respectively in last instar larvae when they were applied at a dose of 100 IJs / dish (Table 2).

Table 2. The effect of different concentrations of Heterorhabditis bacteriophora $(\mathrm{Hb})$ and Steinernema carpocapsae (Sc) on mortality of $4^{\text {th }}$ and $5^{\text {th }}$ instar larvae of the common cutworm (Agrotis segetum) on filter paper

\begin{tabular}{|c|c|c|c|c|c|c|c|}
\hline \multirow{2}{*}{$\begin{array}{l}\text { EPN } \\
\text { species }\end{array}$} & \multirow{2}{*}{$\begin{array}{l}\text { No. of } \\
\text { IJs }^{a}\end{array}$} & \multicolumn{3}{|c|}{$\%$ dead L4 (mean \pm SE) ${ }^{b}$} & \multicolumn{3}{|c|}{$\%$ dead L5 $(\text { mean } \pm \text { SE })^{b}$} \\
\hline & & $12 \mathrm{~h}$ & $24 \mathrm{~h}$ & $48 \mathrm{~h}$ & $12 \mathrm{~h}$ & $24 \mathrm{~h}$ & $48 \mathrm{~h}$ \\
\hline \multirow{4}{*}{$\mathrm{Hb}$} & 25 & $33 \pm 2.5$ e $E$ & $39 \pm 1.8 \mathrm{~d} C D$ & $41 \pm 1.9 \mathrm{~d} \mathrm{BC}$ & $39 \pm 1.9$ c CD & $46 \pm 1.8$ e $A B$ & $49 \pm 1.9$ e $A$ \\
\hline & 50 & $55 \pm 3.5$ c C & $70 \pm 2.2 b \mathrm{bB}$ & $75 \pm 2.3 \mathrm{~b} \mathrm{~A}$ & $65 \pm 4.5 \mathrm{~b} \mathrm{~B}$ & $73 \pm 2.5$ bc $A B$ & $79 \pm 1.9 \mathrm{c} \mathrm{A}$ \\
\hline & 100 & $72 \pm 2.5 a \mathrm{D}$ & $83 \pm 1.2$ a BC & $89 \pm 2.9$ a B & $77 \pm 2.5$ a CD & $88 \pm 1.2$ a B & $98 \pm 1.2$ a $A$ \\
\hline & 200 & $61 \pm 1.9$ bc D & $70 \pm 2.2 b \mathrm{bC}$ & $76 \pm 1.7 b \mathrm{bB}$ & $67 \pm 2.5 \mathrm{~b} \mathrm{C}$ & $73 \pm 1.2 \mathrm{bc} B C$ & $80 \pm 2.2 \mathrm{c} \mathrm{A}$ \\
\hline \multirow{4}{*}{ Sc } & 25 & $23 \pm 2.5 \mathrm{fB}$ & $29 \pm 1.9$ e $A B$ & $32 \pm 2.6$ e $A$ & $27 \pm 2.5 d A B$ & $28 \pm 2.5 \mathrm{f} \mathrm{AB}$ & $34 \pm 1.9 \mathrm{fA}$ \\
\hline & 50 & $41 \pm 1.8 \mathrm{~d} D$ & $49 \pm 1.8$ c BC & $54 \pm 1.9$ c AB & $46 \pm 1.9$ c CD & $53 \pm 2.5 \mathrm{~d} B$ & $60 \pm 2.2 \mathrm{~d} \mathrm{~A}$ \\
\hline & 100 & $66 \pm 2.9 \mathrm{ab} D$ & $69 \pm 2.7$ b CD & $76 \pm 1.8 \mathrm{~b} \mathrm{BC}$ & $68 \pm 2.5 b \mathrm{D}$ & $79 \pm 1.9 \mathrm{~b} \mathrm{~B}$ & $87 \pm 2.5 b$ A \\
\hline & 200 & $66 \pm 1.7 a b C$ & $69 \pm 2.9$ b BC & $73 \pm 1.2 b \mathrm{~B}$ & $66 \pm 1.8 b \mathrm{~b}$ & $71 \pm 1.9$ с BC & $79 \pm 1.9 \mathrm{c} \mathrm{A}$ \\
\hline
\end{tabular}

${ }^{a}$ the number of infective juveniles in each $100 \times 15 \mathrm{~mm}$ Petri dish.

b Mean values followed by different lowercase letters in the same column, or followed by different uppercase letters on the same row are significantly different according to Duncan's test $(P<0.05)$. Each treatment had five replications.

After $48 \mathrm{~h}$, the mortality of pre-pupa and pupa of $A$. segetum significantly differed according to nematode species $(\mathrm{N})$, nematode concentration $(\mathrm{C})$, and their interaction $(\mathrm{N} \times \mathrm{C})$ (Table 3). However, no significant effect of nematode species and nematode concentration was observed after $72 \mathrm{~h}$ of exposure (Table 3). After 48 or 72 h, H. bacteriophora caused greater mortality to pre-pupa and pupa than did $S$. carpocapsae. At the similar time of exposure, the highest level of parasitizing occurred at the highest dose of EPNs (200 IJs $\mathrm{cm}^{-2}$ soil). 
Pre-pupae were more vulnerable to both EPN species than pupae. Mortality percent increased as the time of exposure increased (Table 4). When IJs of $H$. bacteriophora were applied at a dose of $200 \mathrm{IJS}$ $\mathrm{cm}^{-2}$ of soil, 80 and $66 \%$ of pre-pupa and pupa were respectively killed after $72 \mathrm{~h}$. Infection rate of prepupa and pupa by S. carpocapsae was respectively 76 and 50 percent $72 \mathrm{~h}$ after inoculation with a 200 IJs $\mathrm{cm}^{-2}$ soil (Table 4).

Table 3. Analysis of variance for mortality of pre-pupae and pupae of Agrotis segetum in soil when they exposed to three different concentrations $\left(50,100\right.$ and $200 \mathrm{JJs} / \mathrm{cm}^{2}$ soil) of Heterorhabditis bacteriophora and Steinernema carpocapsae in a factorial design

\begin{tabular}{|c|c|c|c|c|}
\hline \multirow{3}{*}{ Source $^{a}$} & \multicolumn{4}{|c|}{ Mean squares } \\
\hline & \multicolumn{2}{|c|}{ Pre-pupae mortality percent ${ }^{b}$} & \multicolumn{2}{|c|}{ pupae mortality percent $^{\mathrm{b}}$} \\
\hline & $48 \mathrm{~h}$ & $72 \mathrm{~h}$ & $48 \mathrm{~h}$ & $72 \mathrm{~h}$ \\
\hline $\mathrm{N}$ & $907.5^{\star *}$ & $163.3^{*}$ & $1333.3^{* *}$ & $213.3^{*}$ \\
\hline C & $6070^{* *}$ & $5923.3^{* *}$ & $6107.5^{* *}$ & $2822.5^{* *}$ \\
\hline $\mathrm{N} \times \mathrm{C}$ & $270^{\star *}$ & $3.3^{\mathrm{ns}}$ & $425.8^{* *}$ & $55.8^{\text {ns }}$ \\
\hline Error & 20 & 29.2 & 22.9 & 27.1 \\
\hline C.V. (\%) & 35.6 & 19.1 & 21.8 & 33.4 \\
\hline
\end{tabular}

ns $,,^{* *}:$ : Non significant, significant at $5 \%$ and $1 \%$ probability levels, respectively.

${ }^{a} \mathrm{~N}=$ nematode species, $\mathrm{C}=$ nematode concentration

$\mathrm{b}$ The corrected mortality percents were considered for analysis.

Table 4. The effect of different concentrations of Heterorhabditis bacteriophora $(\mathrm{Hb})$ and Steinernema carpocapsae (Sc) on mortality of pre-pupa and pupa of the common cutworm (Agrotis segetum) in soil in laboratory experiment

\begin{tabular}{|c|c|c|c|c|c|}
\hline \multirow{2}{*}{$\begin{array}{l}\text { EPN } \\
\text { species }\end{array}$} & \multirow{2}{*}{$\begin{array}{l}\text { No. of } \\
\mathrm{IJs}^{\mathrm{a}}\end{array}$} & \multicolumn{2}{|c|}{$\%$ dead pre-pupa (mean \pm SE) ${ }^{b}$} & \multicolumn{2}{|c|}{$\%$ dead pupa (mean \pm SE) ${ }^{b}$} \\
\hline & & $48 \mathrm{~h}$ & $72 \mathrm{~h}$ & $48 \mathrm{~h}$ & $72 \mathrm{~h}$ \\
\hline \multirow{3}{*}{$\mathrm{Hb}$} & 50 & $15 \pm 1.6 \mathrm{~d} B$ & $32 \pm 2.5 \mathrm{c} \mathrm{A}$ & $5 \pm 1.6$ e $C$ & $20 \pm 3.2 \mathrm{~d} B$ \\
\hline & 100 & $35 \pm 2.2$ c B & $50 \pm 2.2 \mathrm{~b} \mathrm{~A}$ & $24 \pm 2.9$ c C & $40 \pm 1.6 \mathrm{~b} \mathrm{~B}$ \\
\hline & 200 & $73 \pm 2.5$ a $A B$ & $80 \pm 2.2$ a A & $50 \pm 1.6$ a $C$ & $66 \pm 2.9$ a B \\
\hline \multirow{3}{*}{ Sc } & 50 & $10 \pm 1.6 \mathrm{~d} \mathrm{~B}$ & $28 \pm 2.5 \mathrm{c} \mathrm{A}$ & $2 \pm 1.2$ e $C$ & $13 \pm 1.2$ e $B$ \\
\hline & 100 & $30 \pm 2.2$ c B & $44 \pm 1.9 \mathrm{~b} \mathrm{~A}$ & $15 \pm 2.3 \mathrm{~d} C$ & $31 \pm 1.9$ c B \\
\hline & 200 & $50 \pm 1.6 \mathrm{~b} \mathrm{~B}$ & $76 \pm 2.9$ a $A$ & $38 \pm 1.2 b \mathrm{C}$ & $50 \pm 3.5$ a B \\
\hline
\end{tabular}

${ }^{a}$ the number of infective juveniles per $\mathrm{cm}^{2}$ of soil. IJs were applied onto the soil surface in Petri dish.

${ }^{b}$ Mean values followed by different uppercase letters on the same row, or followed by different lowercase letters in the same column are significantly different according to Duncan's test $(P<0.05)$. Each treatment had five replications.

The estimated $L D_{50}$ of each nematode species on two developmental stages $\left(L_{4}\right.$ and $\left.L_{5}\right)$ of the common cutworm at certain time after inoculation is presented in table 5. The $\mathrm{LD}_{90}$ was calculated when it was applicable. The required number of both EPNs for killing $50 \%$ of each developmental stage of the pest decreased with increase in exposure time. 
Effects of entomopathogenic nematodes, Heterorhabditis bacteriophora (Poinar) and Steinernema carpocapsae (Weiser), in biological control of Agrotis segetum (Denis \& Schiffermüller) (Lepidoptera: Noctuidae)

Table 5. The calculated $\mathrm{LD}_{50}$ or $\mathrm{LD}_{90}$ of $H$. bacteriophora and $S$. carpocapsae on the penultimate and last instar larvae of the common cutworm at different exposure times

\begin{tabular}{|c|c|c|c|c|c|c|c|}
\hline \multirow{2}{*}{$\begin{array}{l}\text { Growth } \\
\text { stage }\end{array}$} & \multirow{2}{*}{ Time (h) } & \multicolumn{3}{|c|}{ Heterorhabditis bacteriophora } & \multicolumn{3}{|c|}{ Steinernema carpocapsae } \\
\hline & & $\mathrm{LD}_{50}$ & $\mathrm{LD}_{90}$ & $R^{2 a}$ & $\mathrm{LD}_{50}$ & $\mathrm{LD}_{90}$ & $R^{2 \mathrm{a}}$ \\
\hline \multirow{3}{*}{$\mathrm{L}_{4}$} & 12 & 43 & - & 0.87 & 65 & - & 0.94 \\
\hline & 24 & 32 & - & 0.95 & 51 & - & 0.92 \\
\hline & 48 & 30 & - & 0.94 & 45 & - & 0.95 \\
\hline \multirow{3}{*}{$\mathrm{L}_{5}$} & 12 & 34 & - & 0.84 & 56 & - & 0.93 \\
\hline & 24 & 28 & - & 0.95 & 47 & - & 0.95 \\
\hline & 48 & 25 & 65 & 0.96 & 39 & 114 & 0.96 \\
\hline
\end{tabular}

${ }^{\mathrm{a}} R^{2}$ shows the coefficient of determination for fitting data in each regression model.

\section{Greenhouse experiment}

The virulence of the both EPNs against the common cutworm was similar in greenhouse. No significant difference was found between $H$. bacteriophora and $S$. carpocapsae when the same concentration of them was applied on the same developmental stage of $A$. segetum.

The last instar larvae of $A$. segetum were more vulnerable to both nematode species than other developmental stages were (Figures 1 and 2). The least susceptible developmental stages to $H$. bacteriophora were second and third instar larvae while the least susceptible developmental stage to $S$. carpocapsae was pupa. The best nematode dose for control of nearly all developmental stages of the

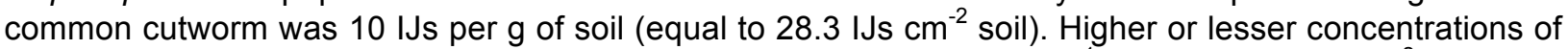
EPNs resulted in lesser efficacy against $A$. segetum; however, $8 \mathrm{IJs} \mathrm{g}^{-1}$ soil (= $\left.25.5 \mathrm{IJs} \mathrm{cm}^{-2} \mathrm{soil}\right)$ was more effective compared with $20 \mathrm{IJs} \mathrm{g}^{-1}$ soil (=56.6 IJs cm $\mathrm{Is}^{-2}$ soil).

Application of $H$. bacteriophora on soil surface of tomato pots resulted in a maximum $98 \%$ kill of fifth instar larvae five days after inoculation with a dose of $10 \mathrm{IJ} \mathrm{g} \mathrm{g}^{-1}$ soil. Only $54 \%$ of $2^{\text {nd }}$ instar larvae were infected by $H$. bacteriophora when it was applied at a dose of $20 \mathrm{IJs} \mathrm{g}^{-1}$ soil (Figure 1).

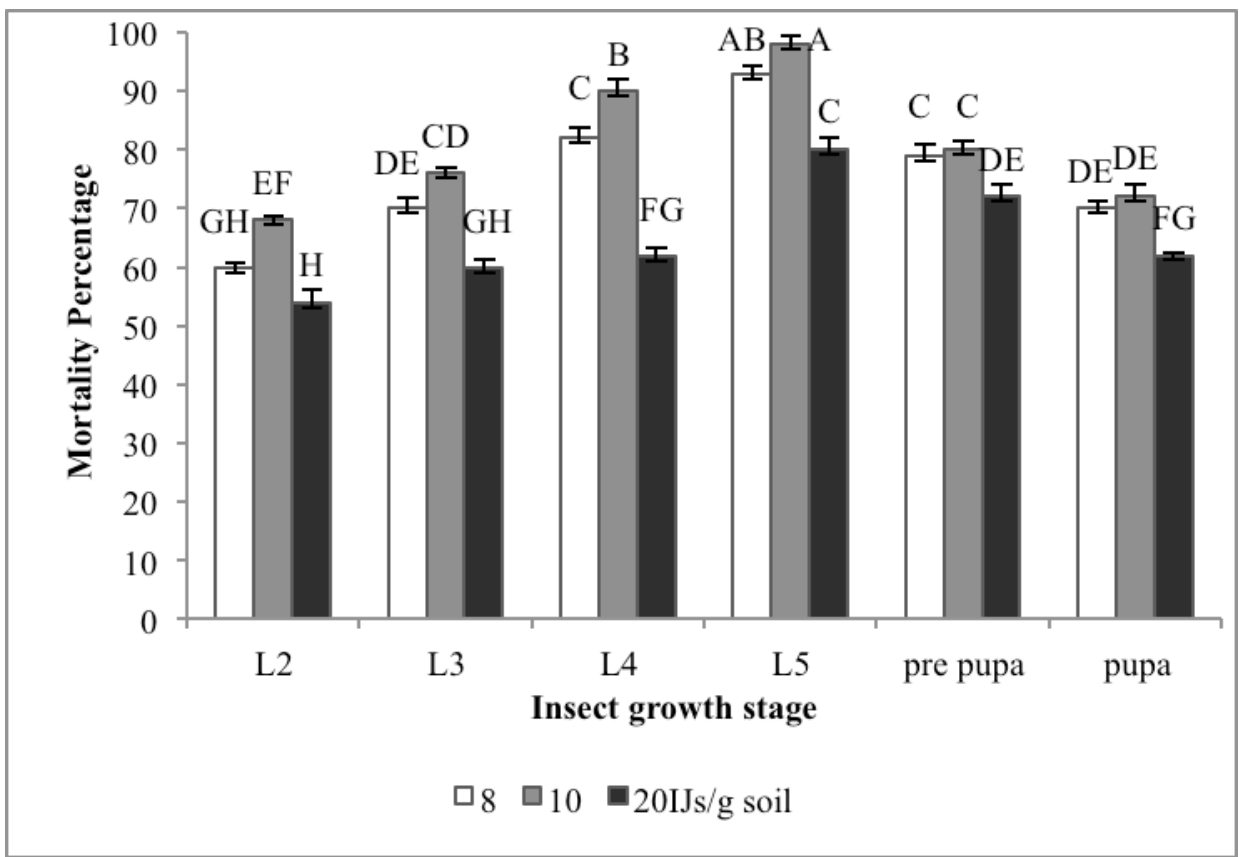

Figure 1. Corrected mortality percent of different developmental stages of the common cutworm five days after inoculation with three concentrations of Heterorhabditis bacteriophora in tomato pots. Bars on the columns correspond to standard error. Each treatment had five replications. Columns with the similar letter(s) are not significantly different $(P<0.05)$. 
The S. carpocapsae respectively caused $90 \%$ and $85 \%$ mortality in $5^{\text {th }}$ and $4^{\text {th }}$ instar larvae when it was applied at a dose of $10 \mathrm{IJs} \mathrm{g}^{-1}$ soil. Eight IJs $\mathrm{g}^{-1}$ soil was more virulent to all insect's developmental stages than $20 \mathrm{IJs} \mathrm{g}^{-1}$ soil was, except for pupal stage. Contrary to other treatments, pupal's infection by $S$. carpocapsae increased when the application dose of IJs per gram of soil was increased (Figure 2).

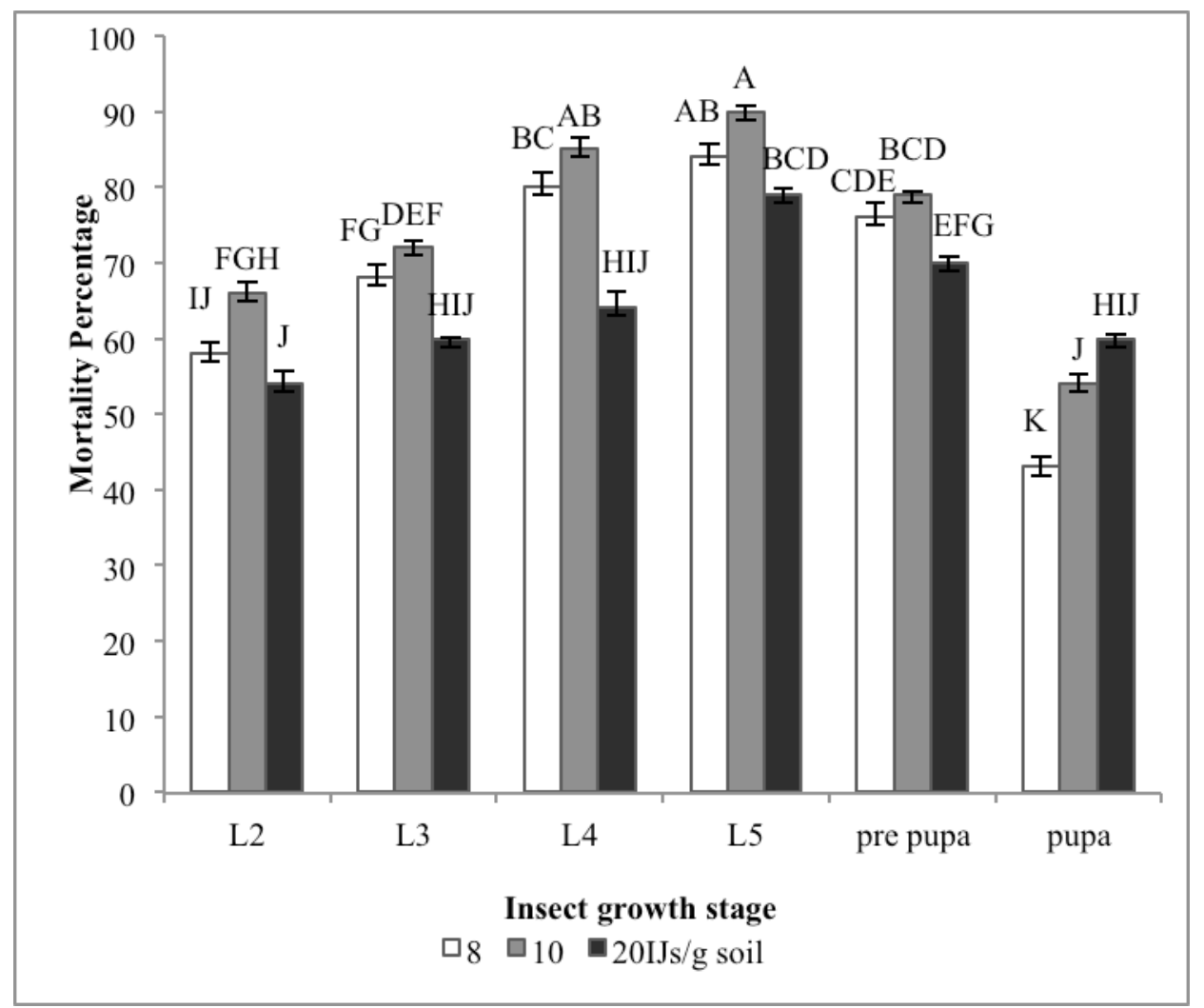

Figure 2.Corrected mortality percent of different developmental stages of the common cutworm five days after inoculation with three concentrations of Steinernema carpocapsae in tomato pots. Bars on the columns correspond to standard error. Each treatment had five replications. Columns with the similar letter(s) are not significantly different $(P<0.05)$.

\section{Discussion}

EPNs have been successfully employed as efficient biocontrol agents against the larvae of some noctuids, including Agrotis ipsilon (Hufnagel) and A. segetum in some Asian or European countries (Georgis et al., 2006; Kaya et al., 2006; Lacey \& Georgis, 2012). Both Heterorhabditis spp. and Steinernema spp. are considered as promising biological control agents of important insect pests due to their ability to seek target hosts, kill hosts rapidly, being safe to non-target organisms and having no threat to the environment-as compared to chemical insecticides (Vashisth et al., 2013).

On filter paper, $H$. bacteriophora provided a more efficient control of the common cutworm's larvae. Increasing in time of exposure caused more mortality in $4^{\text {th }}$ and $5^{\text {th }}$ instar larvae for both nematode species (Table 2). Similar results have been repeatedly reported in which increasing exposure time raised the mortality rate of most developmental stages (Capinera et al., 1988; Jackson \& Brooks, 1995; Ansari et al., 2006; Ebssa \& Koppenhöfer, 2012; Gökçe et al., 2013; Kamali et al., 2013) due to increasing the possibility of encountering with and penetrating into the insect by IJs.

Insect's larval $\left(L_{4}\right.$ and $\left.L_{5}\right)$ mortality was IJs-does-dependant. It is suggested that exposing insect hosts to higher dose of EPNs may obfuscate host recognition and decrease host mortality (Lewis, 2002). Though the filter paper technique cannot simulate field conditions accurately, it is usually used as a quick method of efficacy assessment (Capinera et al., 1988). 
Effects of entomopathogenic nematodes, Heterorhabditis bacteriophora (Poinar) and Steinernema carpocapsae (Weiser), in biological control of Agrotis segetum (Denis \& Schiffermüller) (Lepidoptera: Noctuidae)

The common cutworm pre-pupa was more susceptible to both EPNs rather than pupa. $H$. bacteriophora appeared to act better since it inflicted higher mortality in pre-pupal and pupal stages of insect than S. carpocapsae did. The soil technique surely is more similar to natural conditions (Stock \& Goodrich-Blair, 2012). Pre-pupa further susceptibility may be due to the fact that the natural opening of this developmental stage is not completely sealed yet and its cuticle is thinner.

The $\mathrm{LD}_{50}$ of $H$. bacteriophora on fourth and fifth larval stages of $A$. segetum was lower than those of S. carpocapsae (at similar time span). Because of decline in larval mortality at doses more than 100 IJs, $L D_{90}$ was only calculable after $48 \mathrm{~h}$ and on $L_{5}$ where the mortality percent surpassed $90 \%$. The pathogenicity of EPNs may greatly differ according to different species / isolates (Bedding, 1990; Lacey \& Georgis, 2012). The $L^{2} D_{50}$ of Steinernema kraussei (Steiner) against $A$. segetum third instar larvae was 99 IJs $\mathrm{g}^{-1}$ dry sand seven days after treatment (Gökçe et al., 2013). Application of a Japanese isolate of $S$. carpocapsae against $A$. segetum larvae at a rate of $5 \times 10^{5}$ and $10^{6} \mathrm{IJs} / \mathrm{m}^{2}$ soil respectively caused $67 \%$ and $80 \%$ mortality (Yokomizo \& Kashio, 1996). Among three Turkish Steinernema species, S. feltiae (Filipjev), S. weiseri (Mrácek, Sturhan \& Reid) and S. carpocapsae, the latter was more effective when applied at 10, 25, 50 and 100 IJs per larva (Unlu et al., 2007). The LD $_{50}$ of two isolates of S. carpocapsae (in the original article the species of the nematode was identified as $S$. feltiae according to confusion on the nomenclature at that time) against $A$. ipsilon was determined as 16 and 486 IJs per $100 \mathrm{~g}$ soil (Capinera et al., 1988). Significant variation was also reported for different strains of S. carpocapsae against Curculio caryae (Horn) (Shapiro-llan et al., 2003).

Mortality of successive larval stages of common cutworm progressively increased in pot experiment by both EPN's species with the maximum value seen in $5^{\text {th }}$ instar larvae. Thereafter the susceptibility reduced for pre-pupae and pupae. This pattern of susceptibility is consistent with earlier studies (Shannag et al., 1994; Jackson \& Brooks, 1995; Kim et al., 2004; Ebssa \& Koppenhöfer, 2012). Variation in vulnerability of different developmental stages of insect hosts has been chiefly ascribed to differences in the size or accessibility of body natural openings (mouth, spiracles and anus) which serve as a gate for entrance of nematode IJs (Dowds \& Peters, 2002). On the other hand, older larvae with larger body size may attract more IJs (Smits et al., 1994). For noctuids, stage susceptibility may also be affected by variation in feeding activity. Susceptibility of unfed insect larvae was more than fed ones at lower nematode inoculum doses. Emergence of IJs from unfed insect larval cadaver was also faster and more frequent than from cadavers of fed ones (Kondo, 1987).

Pre-pupa and pupa were less susceptible to tested EPNs than most larval stages were. Less available natural opening for entering IJs to pupae can reduce pupal vulnerability. Only spiracles remain open at pupal stage and the mouth and anus are sealed. The cuticle of pupae is also thicker than in the larval stages and resists more against IJs penetration (Dowds \& Peters, 2002). Pupae are considered as a relative inactive stage with minimum metabolism. At this stage, volatile cues emission (especially $\mathrm{CO}_{2}$ ) by pupae is significantly decreased than by larval stages making pupae less attractive to IJs (Lewis et al., 1993, 1995).

There was no significant difference between virulence of $H$. bacteriophora and $S$. carpocapsae against the common cutworm in pot experiment. Search tactics and dispersal pattern of IJs in soil govern infectivity level (Griffin et al., 2005). Foraging strategy of S. carpocapsae IJs is ambushing (Campbell \& Gaugler, 1993) while H. bacteriophora IJs are cruiser (Lewis, 2002). S. carpocapsae IJs usually inhabit the upper 1-2 cm of the soil while $H$. bacteriophora IJs are distributed evenly in the top $8 \mathrm{~cm}$ of soil (Ferguson et al., 1995; Campbell et al., 1996). As well, IJs of S. carpocapsae tend to move toward the surface of the soil (Georgis \& Poinar, 1983) but IJs of $H$. bacteriophora move both upwards and throughout the soil column (Schroeder \& Beavers, 1987). Though S. carpocapsae is a sit-and-wait strategist (ambusher), it can efficiently parasitize mobile host species (like cutworms) near the soil surface (Hazir et al., 2003). H. bacteriophora is highly mobile and orients to volatile host cues (Hazir et al., 2003). In this study the different developmental stages of the pest were put at the depth of $2 \mathrm{~cm}$. Movement of the common cutworm's larval stages in the soil enhances the chance of confronting with the infective juveniles of the both species of EPNs. These factors along with dispersal pattern of both EPNs may be the reason of similar virulence against $A$. segetum. 
The efficacy of $S$. carpocapsae and $H$. bacteriophora against cutworms were inconsistent in previous studies. S. carpocapsae was highly virulent $(95 \%)$ to $A$. ipsilon, while $H$. bacteriophora did not provided sufficient control (62\%) (Georgis \& Poinar, 1994). When four commercial products containing $H$. bacteriophora, S. carpocapsae, S. feltiae and S. riobrave (Cabanillas, Poinar \& Raulston) were applied against the fourth-instar of $A$. ipsilon in turfgrass, $S$. carpocapsae was the best performing species. Though the efficacy of $H$. bacteriophora and $S$. feltiae was often like to $S$. carpocapsae, their overall consistency were lesser (Ebssa \& Koppenhöfer, 2011). Six isolates of EPNs (S. carpocapsae All, S. carpocapsae Mex, S. feltiae T319, S. longicaudum X-7 (Shen \& Wang), H. bacteriophora H06 and H. indica LN2 (Poinar, Karunakar \& David)) were tested against $A$. ipsilon in a laboratory and field experiments in china. S. carpocapsae Mex and Heterorhabditis indica LN2 were the most effective species and could respectively kill 80 and $83.3 \%$ of $3^{\text {rd }}$ instar larvae after $72 \mathrm{~h}$ (Yan et al., 2014). The pathogenicity of ten Canadian (from three species: S. carpocapsae, S. feltiae, and S. kraussei ((Steiner) Travassos)) and two commercial (from two species: $S$. carpocapsae and $S$. feltiae) isolates of EPNs were tested against $A$. ipsilon in a laboratory experiment. Both commercial $(98 \%$ at the 1000 IJs concentration after $72 \mathrm{~h}$ ) and a Canadian ( $94 \%$ at $250 \mathrm{lJs} /$ larva / Petri dish after $72 \mathrm{~h}$ ) isolates of S. carpocapsae could effectively control the pest (Bélair et al., 2013). When S. carpocapsae and $H$. bacteriophora were sprayed on above ground of corn at a rate of $5 \times 10^{5} \mathrm{IJs} / 150$ plants, they could respectively kill 96.7 and $68.7 \%$ of $A$. ipsilon larvae (Saleh et al., 2015). Steinernema websteri was recently isolated from $A$. segetum in Turkey and could efficiently control this pest. The nematode killed $100 \%$ of third instar larvae in 5 days when it was applied with the concentration of 500 IJs / g dry sand (Gökçe et al., 2015).

The results of current research suggest that both $H$. bacteriophora and $S$. carpocapsae can be used to control the common cutworm. Future work in an open field situation should be done to emphasize the potential of these two candidates in biological control of $A$. segetum.

\section{Acknowledgements}

This project is supported by the Marvdasht Branch, Islamic Azad University. The financial help are sincerely acknowledged by the authors.

\section{References}

Abbott, W.S., 1925. A method of computing the effectiveness of an insecticide. Journal of Economic Entomology, 18: 265-276.

Adams, B.J., A. Fodor, H.S. Koppenhöfer, E. Stackebrandt, S.P. Stock \& M.G. Klein, 2006. Biodiversity and systematics of nematode-bacterium entomopathogens. Biological Control, 37: 32-49.

Ansari, M.A., A. Farman \& M. Moens, 2006. Compared virulence of the Belgian isolate of Steinernema glaseri (Rhabditida: Steinernematidae) and the type population of $S$. scarabaei to white grub species (Coleoptera: Scarabaeidae). Nematology, 8: 787-791.

Bedding, R.A., 1990.“Logistics and strategies for introducing entomopathogenic nematode technology in developing countries, 233-248”. In: Entomopathogenic Nematodes for Biological Control (Eds: R. Gaugler \& H.K. Kaya), CRC Press, Boca Raton, $365 \mathrm{pp}$.

Bélair, G., L. Simard \& J. Dionne, 2013. Canadian entomopathogenic nematode isolates: virulence against black cutworm (Lepidoptera: Noctuidae). Phytoprotection, 93: 43-46.

Bourner, T.C., E. Vargas-Osuna, T. Willims, C.S. Alvrrez \& J.S. Cory, 1992. A comparison of the efficacy of nuclear polyhedrosis and granulosis viruses in spray and bait formulation for the control of Agrotis segetum (Lepidoptera: Noctuidae) in maize. Biocontrol Science and Technology, 2: 315-326.

Bowden, J., J. Cochrane, B.J. Emmett, T.E. Minall \& P.L. Shperlock, 1983. A survey of cutworm attack in England and Wales, and a descriptive population model for Agrotis segetum (Lepidoptera: Noctuidae). Annals of Applied Biology, 102: 29-47.

Campbell, J.F. \& R. Gaugler, 1993. Nictation behaviour and its ecological implications in the host search strategies of entomopathogenic nematodes (Heterorhabditidae and Steinernematidae). Behaviour, 126: 155-169. 
Effects of entomopathogenic nematodes, Heterorhabditis bacteriophora (Poinar) and Steinernema carpocapsae (Weiser), in biological control of Agrotis segetum (Denis \& Schiffermüller) (Lepidoptera: Noctuidae)

Campbell, J.F., E.E. Lewis, F. Yoder \& R. Gaugler, 1996.Spatial and temporal distribution of entomopathogenic nematodes in turf. Parasitology, 113: 473-482.

Capinera, J.L., D. Pelissier, G.S. Menout \& N.D. Epsky, 1988. Control of black cutworm, Agrotis ipsilon (Lepidoptera: Noctuidae), with entomogenous nematodes (Nematoda: Steinernematidae, Heterorhabditidae). Journal of Invertebrate Pathology, 52: 427-435.

Damani Zamani, F., M.R. Moosavi \& R. Asadi, 2015. Pathogenicity of Steinernema carpocapsae and Heterorhabditis bacteriophora on tomato leafminer, Tuta absoluta. Biocontrol in Plant Protection, 3: (accepted-in Persian).

Dowds, B.C.A. \& A. Peters, 2002. "Virulence mechanisms, 79-98". In: Entomopathogenic Nematology (Ed: R. Gaugle), CAB International, Wallingford, $388 \mathrm{pp}$.

Ebssa, L. \& A.M. Koppenhöfer, 2012. Efficacy and persistence of entomopathogenic nematodes for black cutworm control in turfgrass. Biocontrol Science and Technology, 21: 779-796.

Ebssa, L. \& A.M. Koppenhöfer, 2012. Entomopathogenic nematodes for the management of Agrotis ipsilon: effect of instar, nematode species and nematode production method. Pest Management Science, 68: 947-57.

Ehler, L.E., 1990. "Some contemporary issues in biological control of insects and their relevance to the use of entomopathogenic nematodes, 1-19". In: Entomopathogenic Nematodes for Biological Control (Eds: R. Gaugler\& H. K. Kaya), CRC Press, Boca Raton, 365 pp.

Ehlers, R.-U. \& D.I. Shapiro-llan, 2005."Mass production, 65-78”. In: Nematodes as Biocontrol Agents (Eds: P. S. Grewal, R. -U. Ehlers \& D. I. Shapiro-Ilan), CAB International, Wallingford, 505 pp.

Ferguson, C.S., P.C. Schroeder \& E.J. Shields, 1995. Vertical distribution, persistence, and activity of entomopathogenic nematodes (Nematoda: Heterorhabditidae and Steinernematidae) in alfalfa snout beetle (Coleoptera: Curculionidae) infested fields. Environmental Entomology, 24: 149-158.

Georgis, R. \& G.O.Jr. Poinar, 1994. "Nematodes as bioinsecticides in turf and ornamentals, 477-489". In: Handbook of Integrated Pest Management for Turf and Ornamentals (Ed: A. Leslie), CRC Press, Boca Raton, 273 pp.

Georgis, R. \& G.O.Jr. Poinar, 1983. Effect of soil texture on the distribution and infectivity of Neoaplectana carpocapsae (Nematoda: Steinernematidae). Nematology, 15: 308-311.

Georgis, R., A.M. Koppenhöfer, L.A. Lacey, G. Belair, L.W. Duncan, P.S. Grewal, M. Samish, L. Tan, P. Torr \& R.W.H.M. Van Tol, 2006. Successes and failures in the use of parasitic nematodes for pest control. Biological Control, 38: 103-123.

Gökçe, C., H. Yilmaz, Z. Erbas, Z. Demirbağ \& I. Demir, 2013. First record of Steinernema kraussei (Rhabditida: Steinernematidae) from Turkey and its virulence against Agrotis segetum (Lepidoptera: Noctuidae). Nematology, 45: 253-259.

Gökçe, C., Z. Erbas, H. Yilmaz, Z. Demirbağ \& İ. Demir, 2015. A new entomopathogenic nematode species from Turkey, Steinernema websteri (Rhabditida: Steinernematidae), and its virulence. Turkish Journal of Biology, 39: 167-174.

Griffin, C.T., N.E. Boemare \& E.E. Lewis, 2005."Biology and behaviour, 47-64". In: Nematodes as Biocontrol Agents (Eds: P. S. Grewal, R. -U. Ehlers \& D. I. Shapiro-llan), CAB International, Wallingford, 505 pp.

Hazir, S., H.K. Kaya, S.P. Stock \& N. Keskin, 2003. Entomopathogenic nematodes (Steinernematidae and Heterorhabditidae) for biological control of soil pests. Turkish Journal of Biology, 27: 181-202.

Hominick, W.M., 2002. "Biogeography, 115-143”. In: Entomopathogenic Nematology (Ed: R. Gaugler), CABI Publishing, Wallingford, $388 \mathrm{pp}$.

Hunt, D.J., 2007. "Introduction, 1-26". In: Entomopathogenic Nematodes: Systematics, Phylogeny and Bacterial Symbionts, Nematology monographs and perspectives ((Eds; K. B. Nguyen \& D. J. Hunt), Series Eds: D. J. Hunt \& R. N. Perry), Vol 5. Koninklijke Brill NV, Leiden, 816 pp.

Jackson, J.J. \& M.A. Brooks, 1995. Parasitism of western corn rootworm larvae and pupae by Steinernema carpocapsae. Nematology, 27: 15-20.

Jakubowska, A., M.M. Van Oers, J. Ziemnicka, J.J. Lipa \& J.M. Valk, 2005. Molecular characterization of Agrotis segetum nucleopolyhedrovirus from Poland. Journal of Invertebrate Pathology, 90: 64-68. 
Kamali, Sh., J. Karimi, M. Hosseini, R. Campos-Herrera \& L.W. Duncan, 2013. Biocontrol potential of the entomopathogenic nematodes Heterorhabditis bacteriophora and Steinernema carpocapsae on cucurbit fly, Dacus ciliatus (Diptera: Tephritidae). Biocontrol Science and Technology, 23: 1307-1323.

Kaya, H.K., M.M. Aguillera, A. Alumai, H.Y. Choo, M. De la Torre, A. Fodor, S. Ganguly, S. Hazır, T. Lakatos, A. Pye, M. Wilson, S. Yamanaka, H. Yangm \& R.-U. Ehlers, 2006. Status of entomopathogenic nematodes and their symbiotic bacteria from selected countries or regions of the world. Biological control, 38: 134-155.

Kim, H.H., H.Y. Choo, H.K. Kaya, D.W. Lee, S.M. Lee \& H.Y. Jeon, 2004. Steinernema carpocapsae (Rhabditida: Steinernematidae) as a biological control agent against the fungus Gnat Bradysia agrestis (Diptera: Sciaridae) in propagation houses. Biocontrol Science and Technology, 14: 171-183.

Kondo, E., 1987. Size-related susceptibility of Spodoptera litura (Lepidoptera: Noctuidae) larvae to entomogenous nematode, Steinernema feltiae (DD-136). Applied Entomology and Zoology, 22: 560-569.

Koppenhöfer, A.M. \& H.K. Kaya, 2002. "Entomopathogenic nematodes and insect pest management, 258-313". In: Microbial Biopesticides (Eds: O. Koul \& G.S. Dhaliwal), Taylor \& Francis, Abingdon, 332 pp.

Koppenhöfer, A.M., 2000. "Nematodes, 283-301". In: Field Manual of Techniques in Invertebrate Pathology (Eds: L.A. Lacey \& H.K. Kaya). Kluwer, Dordrecht, 911 pp.

Lacey, L.A. \& R. Georgis, 2012. Entomopathogenic nematodes for control of insect pests above and below ground with comments on commercial production. Journal of Nematology, 44: 218-225.

Lewis, E.E., 2002. "Behavioural ecology, 205-223". In: Entomopathogenic Nematology (Ed: R. Gaugle). CAB International, Wallingford, $388 \mathrm{pp}$.

Lewis, E.E., P.S. Grewal \& R. Gaugler, 1995. Hierarchical order of host cues in parasite foraging strategies. Parasitology, 110: 207-213.

Lewis, E.E., R. Gaugler \& R. Harrison, 1993. Response of cruiser and ambusher entomopathogenic nematodes (Steinernematidae) to host volatile cues. Canadian Journal of Zoology, 71: 765-769.

Metwally, H.M.S., G.A. Hafez, M.A. Hussein, M.A. Hussein, H.A., Salem \& M.M.E. Saleh, 2012. Low cost artificial diet for rearing the greater wax moth, Galleria mellonella L. (Lepidoptera: Pyralidae) as a host for entomopathogenic nematodes. Egyptian Journal of Biological Pest Control, 22: 15-17.

Moosavi, M.R. \& R. Zare, 2012. "Fungi as biological control agents of plant-parasitic nematodes, 67-107". In: Plant Defence: Biological Control (Progress in Biological Control 12) (Eds: J. M. Merillon \& K. G. Ramawat). Springer Science + Business Media, Dordrecht, 412 pp.

Moosavi, M.R. \& R. Zare, 2015."Factors affecting commercial success of biocontrol agents of phytonematodes, 423445". In: Biocontrol Agents of Phytonematodes (Eds: T. H. Askary\& P. R. P. Martinelli), CABI Publishing, Wallingford, $500 \mathrm{pp}$.

Nguyen, K. B., 2007. "Methodology, morphology and identification, 59-119". In: Entomopathogenic Nematodes: Systematics, Phylogeny and Bacterial Symbionts, Nematology monographs and perspectives (Eds; K. B. Nguyen \& D. J. Hunt), Series Eds: D. J. Hunt \& R. N. Perry), Vol 5. Koninklijke Brill NV, Leiden, 816 pp.

Rosen, W., 2002. Endogenous control of circadian rhythms of pheromone production in the turnip moth, Agrotis segetum. Archives of Insect Biochemistry and Physiology, 50: 21-30.

Saleh, M.M.E., M.A. Hussein, G.A. Hafez, M.A. Hussein, H.A. Salem \& H.M.S. Metwally, 2015. Foliar application of entomopathogenic nematodes for controlling Spodoptera littoralis and Agrotis ipsilon (Lepidoptera: Noctuidae) on corn plants. Advances in Applied Agricultural Science, 3: 51-61.

SAS. 1990. SAS/STATuser'sversion 6, $4^{\text {th }}$ edition. Vol. 1 \& 2. Cary: SAS Institute Inc.

Schroeder, W.J. \& J.B. Beavers, 1987. Movement of the entomogenous nematodes of the families Heterorhabditidae and Steinernematidae in soil. Nematology, 19: 257-259.

Sevim, A., Z. Demirbag \& I. Demir, 2010. A new study on the bacteria of Agrotis segetum Schiff. (Lepidoptera: Noctuidae) and their insecticidal activities. Turkish Journal of Agriculture and Forestry, 34: 333-342.

Shannag, H.K., S.E. Webb \& J.L. Capinera, 1994. Entomopathogenic nematode effect on pickleworm (Lepidoptera: Pyralidae) under laboratory and field conditions. Journal of Economic Entomology, 87: 1205-1212. 
Effects of entomopathogenic nematodes, Heterorhabditis bacteriophora (Poinar) and Steinernema carpocapsae (Weiser), in biological control of Agrotis segetum (Denis \& Schiffermüller) (Lepidoptera: Noctuidae)

Shapiro-llan, D.I., R. Stuart, C.W. McCoy, 2003.Comparison of beneficial traits among strains of the entomopathogenic nematode, Steinernema carpocapsae, for control of Curculio caryae (Coleoptera: Curculionidae). Biological Control, 28: 129-136.

Sharma, M.P., A.N. Sharma, S.S. Hussaini, 2011. Entomopathogenic nematodes, a potential microbial biopesticide: Mass production and commercialisation status - a mini review. Archives of Phytopathology and Plant Protection, 44: 855-870.

Smits, P.H., G.L. Wiegers \& H.J. Vlug, 1994. Selection of insect parasitic nematodes for biological control of the garden chafer, Phyllopertha horticola. Entomologia Experimentaliset Applicata, 70: 77-82.

Stock, S.P. \& H. Goodrich-Blair, 2012."Nematode parasites, pathogens and associates of insects and invertebrates of economic importance, 373-426". In: Manual of Techniques in Insect Pathology, $2^{\text {nd }}$ edition (Ed: L. A. Lacey), Academic Press, San Diego, 484 pp.

Unlu, I.O., R.-U. Ehlers \& I.A. Susurluk, 2007.Additional data and first record of the entomopathogenic nematode Steinernema weiseri from Turkey. Nematology, 9: 739-741.

Vashisth, S., Y.S. Chandel \& P.K. Sharma, 2013. Entomopathogenic nematodes - A review. Agricultural Reviews, 34: 163-175.

White, G.F., 1927. A method for obtaining infective nematode larvae from cultures. Science, 66: 302-303.

Yan, X., X. Wang, R. Han, \& X. Qiu, 2014. Utilisation of entomopathogenic nematodes, Heterorhabditis spp. and Steinernema spp., for the control of Agrotis ipsilon (Lepidoptera, Noctuidae) in China. Nematology, 16: 31-40.

Yokomizo, K. \& T. Kashio, 1996. Application of an entomogenous nematode, Steinernema carpocapsae, for control of the cutworm, Agrotis segetum, in carrot fields. Proceedings of the Association for Plant Protection of Kyushu, 42: 89-92. 